\title{
Aplikasi Pengenalan Paribasa Bali Berbasis Mobile
}

\author{
Ketut Arya ${ }^{1}$, I Made Agus Wirawan ${ }^{2}$, Gede Aditra Pradnyana ${ }^{3}$ \\ Program Studi Pendidikan Teknik Informatika \\ Jurusan Teknik Informatika \\ Fakultas Teknik dan Kejuruan \\ Universitas Pendidikan Ganesha \\ Email : ketutarya1102@gmail.com ${ }^{1}$, imade.aguswirawan@undiksha.ac.id ${ }^{2}$, gede.aditra@undiksha.ac.id ${ }^{3}$
}

\begin{abstract}
Abstrak - Paribasa Bali merupakan gaya bicara berturut setiap individu masyarakat Bali yang mempunyai fungsi sebagai pemanis dalam berbicara atau menuliskan hasil karya. Berdasarkan survey terhadap 35 orang respoonden diketahui bahwa, semua responden setuju jika Paribasa Bali dapat dipelajari dan dilestarikan melalui aplikasi mobile. Penelitian ini bertujuan: (1) untuk menghasilkan rancangan dan implementasi aplikasi pengenalan Paribasa Bali berbasis mobile. (2) untuk mengetahui respon penguna terhadap aplikasi pengenalan Paribasa Bali berbasis mobile. Penelitian ini menggunakan metode Research and develpoment $(R \& D)$ dengan model yang digunakan adalah ADDIE meliputi, Analysis, Design, Development, Implementation, and Evaluations). Hasi dari penelitian ini adalah aplikasi yang diimplementasikan dengan bahasa pemrograman javasvript dengan framework react native. Hasil yang diperoleh dari pengujian black box dan pengujian whitebox, yaitu semua proses dapat bekerja dengan baik dan sesuai dengan fungsinya.Respon pengguna melaui pengujian UEQ terhadap aplikasi pengenalan Paribasa Bali berbasi mobile masuk dalam rentangan sangat baik.
\end{abstract}

Kata kunci: Paribasa Bali, ADDIE, React Native, Mobile.

Abstract-Paribasa Bali is a successive speaking style of each individual in the Balinese community that has a function as a sweetener in speaking or writing works. Based on a survey of 35 respondents it is known that, all respondents agreed that Paribasa Bali could be studied and preserved through a mobile application. This study aims: (1) to produce the design and implementation of applications for the introduction of mobile-based Bali Paribasa. (2) to find out the response of users to the application of the introduction of Bali-based Paribasa mobile. This research uses Research and Develpoment ( $R \& D)$ method with the model used is
ADDIE including, Analysis, Design, Development, Implementation, and Evaluations). The result of this research is that the application is implemented with the Javasvript programming language with Framework React Native. The results obtained from black box testing and whitebox testing, which are all processes can work well and in accordance with its functions. User responses through UEQ testing of the application for the introduction of Bali-based Paribasa mobile in a very good range.

Keyword: Paribasa Bali, ADDIE, React Native, Mobile.

\section{PENDAHULUAN}

Bali merupakan salah satu dari suku bangsa di Indonesia yang memiliki karakteristik seni dan budaya. Kebudayaan di Bali tentu selalu erat kaitanya dengan kesenian. Berbicara mengenai kesenian, Bali memiliki berbagai kesenian yang salah satunya adalah seni sastra berupa kesustraan Bali. Kesusastraan Bali adalah hasil dari karya pengarang berdasarkan ilham atau wahyu lalu dikarang menggunakan bahasa yang baik dan benar (Riken \& Anom, 1993). Berdasarkan zamannya, kesusastraan Bali dapat dibagi menjadi dua, yaitu kesusastraaan Bali Purwa dan kesusastraaan Bali Anyar. Kesustraan Bali Purwa (lama) merupakan kesusastraan Bali yang diterima atau diwarisi sejak masa lampau, bentuknya ada yang berupa prosa, puisi tradisional, tutur atau satua, mantra, dan paribasa Bali. Kesusastraan Bali Anyar (baru) adalah kesusastraan Bali yang perkembangannya mengikuti bentuk-bentuk kesusastraan nasional dimana bahasanya telah disisipi bahasa asing maupun bahasa Indonesia, bentuknya ada yang berupa prosa, puisi Bali modern, dan drama.

Paribasa Bali adalah salah satu dari sekian bentuk kesustraan Bali Purwa yang ada. Paribasa Bali juga merupakan salah satu aspek dari wujud kebudayaan Bali yang mengandung nilai-nilai luhur serta pandangan hidup bagi masyarakat penuturnya.

Paribasa Bali merupakan gaya bicara berturut setiap individu masyarakat Bali yang mempunyai fungsi sebagai 
pemanis dalam berbicara atau menuliskan hasil karya [1] Paribasa Bali dapat dibagi menjadi sepuluh jenis, yaitu (1) Wewangsalan, (2) Peparikan, (3) Sesonggan, (4) Sesenggakan, (5) Sesawangan, (6) Bladbadan, (7) Sloka, (8) Sesapan, (9) Raos ngempelin, (10) Cacimpedan. Bentuk-bentuk yang termasuk dalam Paribasa Bali ini, yakni menggunakan suatu perumpamaan dalam menyampaikan perimbangan atau keadaan perilaku manusia dengan binatang atau benda. Penggunaan Paribasa Bali ini biasanya disisipi dalam percakapan sehari-hari, pentas seni drama, dan lirik sebuah lagu bali.

Peneliti telah mengadakan survery terhadap 35 orang responden mengenai masalah serta kondisi Paribasa Bali saat ini di masyarakat umum. Berdasarkan dari hasil tersebut maka diketahui bahwa, sebanyak $62 \%$ responden mengetahui manfaat dalam mempelajari Paribasa Bali. Selanjutnya, sebanyak $25 \%$ responden mengetahui secara pasti tentang Paribasa Bali dan adapun sisanya sebanyak $75 \%$ responden tidak mengatahui secara pasti tentang Paribasa Bali. Semua responden setuju jika Paribasa Bali sebagai media belajar dan dilestarikan melalui aplikasi mobile.

Melihat hal tersebut, maka setidaknya perlu memanfaatkan penggunaan teknologi yang berkembang sekarang ini. Pada perkembangan teknologi sekarang ini khusunya smartphone sudah semakin berkembang. Salah satunya smartphone dengan sistem operasi android. Berdasarkan data yang dikeluarkan katadata.co.id android masih mendominasi perangkat mobile di dunia, hali ini dapat ditunjukkan bahwa sebanyak 72,9 persen piranti bergerak global menggunakan android yang mengacu pada laporan yang bertajuk Global in Q3 2017. Selain perkembangan smartphone android, adapun juga beragam aplikasi yang tersedia dan menunjang pengguna. Pengembangan aplikasi kini juga dapat dengan mudah dilakukan oleh pengembang karena banyaknya framework untuk aplikasi mobile yang disediakan. Salah satu framework tersebut adalah react native yang telah dikembangkan oleh Facebook pada tahun 2015. Adanya perkembangan tersebut, apabila dimanfaatkan dengan baik tentu berdampak positif. Khususnya smartphone yang sebelumnya hanya dimanfaatkan sebagai gaya hidup maupun sebagai sarana berkomunikasi, akan lebih bermanfaat lagi jika digunakan sebagai media belajar.

Sebagai solusi permasalahan berdasarkan uraian di atas, penulis tertarik untuk membuat suatu "Aplikasi Pengenalan Baribasa Bali Berbasis Mobile". Aplikasi yang penulis kembangkan memuat sepuluh jenis Paribasa Bali yang ada. Pemilihan berupa aplikasi mobile ini sekiranya tepat untuk mempermudah dalam mempelajari Paribasa Bali karena mudah diakses dimana saja maupun kapan saja melalui smartphone. Konsep pengenalan dari Paribasa Bali yang akan digunakan adalah kamus. Adapun jenis kamus yang tepat digunakan yaitu, kamus peribahasa. Penggunaan jenis kamus ini dikarenakan sesuai dengan karakteristik dari Paribasa Bali, yakni menerangkan maksud, arti atau makna dari suatu ungkapan. Selain Paribasa Bali yang disajikan melalui kamus juga dilengkapi beberapa fitur, seperti daftar dan masuk dengan email, kemudian dapat melihat dan menyukai kiriman Paribasa Bali dari semua pengguna, dan membagikan atau menambahkan Paribasa Bali baru. Sasaran dari aplikasi ini dimulai dari anak-anak hingga orang dewasa. Adanya aplikasi ini juga diharapkan dapat memberikan daya tarik dan kemudahan dalam mempelajari sehingga Paribasa Bali tetap bisa dilestarikan sampai generasi mendatang.

\section{KAJIAN TEORI}

\section{A. Paribasa Bali}

Paribasa Bali merupakan salah satu aspek dari wujud kebudayaan Bali yang mengandung nilai-nilai luhur serta pandangan hidup bagi masyarakat penuturnya. Paribasa Bali merupakan gaya bicara berturut tiap individu masyarakat Bali yang mempunyai fungsi sebagai pemanis dalam berbicara atau menuliskan hasil karya [1].

Paribasa Bali dapat dibagi menjadi sepuluh jenis, yaitu (1) wewangsalan, (2) peparikan, (3) sesonggan, (4) sesenggakan, (5) sesawangan, (6) bladbadan, (7) sloka, (8) sesapan, (9) raos ngempelin, (10) cacimpedan. Berikut ini adalah penjelasan dari masing-masing jenis Paribasa Bali.

1. Wewangsalan

Wewangsalan berasal dari kata "wangsal" yang di reduplikasikan dan mendapat akhiran-an menjadi wewangsalan berarti sindiran. Wangsal atau bangsal adalah nama bangunan tempat orang berkumpul, bersenda gurau, beryanyi-nyayi atau berpantun-pantun yang mengandung sindiran. Berikut ini aadalah contoh dari wewangsalan.

- Asep menyan majagau, nakep lengar aji kau.

\section{Peparikan}

Peparikan berasal dari kata "parik" yang artinya padi dan mendapat tekanan suara k sehingga menjadi suara parik. Kata dari parik mendapat akhiran-an menjadi parikan dan kata ini dijadikan kata pantun menjadi peparikan. Berikut ini adalh contoh dari peparikan.

- Jaja uli tuna, talin umah tan abetih, suba kanti truna tua, ngalih somah bas mamilih.

\section{Sesonggan}

Sesonggan berasal dari kata "ungguh"yang artinya duduk, tempat atau tinggal, dan mendapat akhiran-an menjadi ungguhan. Kata ungguhan disandingkan menjadi unggawan serta dipercepat dalam pengucapannya sehingga menjadi unggan. Selanjutnya, kata unggan mendapat awalan-sa dan disandingkan menjadi songgan. Kemudian di reduplikasikan menjadi sesonggan artinya 
seirama, senasib, sejalan. Berikut ini adalah contoh dari sesonggan.

- Bapanne macan panakne samong, artinya upami bapan ipun dueg dados balian, pianakne ipun taler dueg ngusadanin.

\section{Sesenggakan}

Sesengggakan berasal dari kata "senggak" yang di reduplikasikan dan mendapat akhiran-an menjadi sesengggakan artinya kata-kata kias yang tepat dan benar yang mencengkam maksud sepenuhnya. Kata kiasan ini untuk menyentuh seseorang yang dituju. Berikut ini adalah contoh dari sesengggakan.

- Buka benange, kadung suba maceleban, artinya sakadi anake sane kadung ngambil pakaryan, nyalah-nyalah yening ipun makarya nenten jantos patut.

\section{Sesawangan}

Sesawanggan berasal dari kata "sawang" yang di reduplikasikan serta mendapat akhiran-an menjadi sesawanggan artinya kata-kata yang mengumpamakan budi pekerti, gerakan, keadaan anggota, ketampanan, kecantikan yang dibandingkan dengan keadaan alam sekitarnya. Berikut ini adalah contoh dari sesawanggan.

- Binggung kenehe buka ketanggeb langkit.

\section{Blabadan}

Blabadan berasal dari kata "badbad" yang artinya ulur atau mulur serta mendapat sisipan dari el menjadi beladbad berarti permuluran atau perpanjangan. Karena pengaruh ucapan sehingga menjadi blabadan (e pada el, hilang). Blabadan merupakan kalimat yang dimulurkan atau dipanjangkan sehingga dapat melukiskan maksud pembicara. Berikut ini adalah contoh dari bladbadan.

- Ah, da cai majembok bebek = majembong bebek = jambul, artinya ngambul (merajuk).

\section{Sloka}

Sloka ialah istilah ungkapan kalimat yang terdiri dari beberapa baris dan tiap-tiap baris terdiri dari delapan suku kata bahkan. Sloka adalah kata kiasan yang langsung dibandingkan dengan keadaan benda, binatang, dan sifatsifat benda suatu perbuatan seseorang dengan cara yang halus. Berikut ini adalah contoh dari sloka.

- Buka slokane, dija ada galungan buung, artinya nenten wenten anak jag wangde ngerereh pangupajiwa.

\section{Sesapan}

Sesapan artinya perihal menegur atau menyapa. Sesapan dari kata sapa, isinya kebayakan mengandung maksud permohonan atau pemanjat doa terhadap tuhan maupun kepercayaan lainya demi keselamatannya. Biasanya untuk mengucapkan kata sesapan ini digunakan kata-kata yang sopan dan halus. Berkut ini adalah contoh dari peparikan.

- Sesapan ngentasin genah tenget, jero sane nuenag genahe utawi margine tiang nyelang genahe icen titiang karahajengan.

\section{Raos Ngempelin}

Raos ngempelin artinya madua arti, yaitu sepatah kata atau kalimat yang memiliki dua arti. Kata-kata ini sering digunakan untuk pertengkaran mulut dalam pertujukan pelawak disebabkan salah pengertian atau salah paham penerimanya. Berikut ini adalah contoh dari raos ngempelin.

- Damar bedauh, mati kanginan, artinya kanginan = genah ipun bedangin, kanginan = tempuh angi

10. Cacimpedan

Cacimpedan berasal dari kata "cimped" (terka, tebak) dan mendapat akhiran-an menjadi cimpedan (terkaan, tebakan). Selanjutnya kata dari cimpedan di reduplikasikan menjadi cacimpedan artinya terka-terkaan atau umumnya teka-teki, yakni kalimat untuk mengasah pikiran (otak). Berikut ini adalah contoh dari cacimpedan.

- Maglebuk masuryak, tebakannya papah nyuh tuh (danyuh).

\section{B. Kamus}

Kamus adalah sejenis buku rujukan yang menerangkan makna kata-kata. Selain menerangkan maksud kata, kamus juga mungkin mempunyai pedoman sebutan, asal-usul (etimologi) sesuatu perkataan dan contoh penggunaan bagi suatu perkataan [2]. Salah satu jenis kamus yang sering untuk digunakan yaitu, kamus peribahasa merupakan kamus untuk menerangkan makna, maksud, arti dari suatu ungkapan.

\section{Android}

Android adalah sebuah sistem operasi untuk perangkat mobile berbasis linux yang mecangkup sistem operasi, middleware, dan aplikasi [3]. Android bersama dengan Open Handset Alliance menyatakan mendukung pengembangan open source pada perangkat mobile.

\section{React Native}

React Native adalah framework Javascript yang digunakan untuk membuat aplikasi native yang mampu berjalan di platform android atau IOS [4]. Framework ini berbasis React JS buatan dari Facebook yang digunakan untuk membuat tampilan aplikasi yang berfokus pada aplikasi mobile. 
ISSN 2252-9063

React Native bekerja dengan menanamkan file Javascript yang sudah di-bundle di dalam aplikasi, dan menjalankannya secara local dari aplikasi yang telah dibuat. Selain itu, juga dapat meletakan file Javascript di dalam server dan diambil ketika ada koneksi internet. Hal ini memungkinkan untuk melakukan update aplikasi dengan cepat tanpa melalui submit ke Google Playstore maupun IOS Appstore.

\section{E. Firebase}

Firebase adalah suatu layanan dari google untuk mempermudah para pengembang dalam mengembangkan aplikasi mobile. Adapun fitur yang dimiliki dari firebase, diantarnya Firebase User Authentication dan Firebase Real Time.

- Firebase User Authentication merupakan sebuah layanan yang digunakan untuk mengizikan pengguna login ke aplikasi menggunakan satu atau beberapa metode login, termasuk login dengan alamat email dan sandi, serta penyediaan indentitas tergabung, seperti login dengan Google, Facebook, Twitter dan Github.

- Firebase Realtime Database merupakan database yang di-host di cloud. Data disimpan sebagai JSON dan disinkronkan secara realtime ke setiap client yang terhubung. Ketika pengembang membuat aplikasi lintas platform dengan SDK Android, IOS, dan JavaScript, semua client akan berbagi sebuah instance Realtime Database dan menerima update data terbaru secara otomatis.

\section{METODOLOGI PENELITIAN}

Aplikasi Pengenalan Paribasa Bali Berbasis Mobile menggunakan metode Research and Develpoment (R\&D). Adapun model penelitian yang digunakan yaitu, ADDIE yang merupakan singkatan dari Analysis (analisis), Design (desain), Develpoment (pengembangan), Implemnetation (implementasi), and Evaluation (evaluasi). ADDIE adalah model perancangan intuksional yang berupa proses umum yang secara tradisional digunakan oleh para perancang instruksional atau pengembangan pelatihan [5]. Pada Gambar 1 merupakan model penelitian ADDIE yang diterapkan pada Aplikasi Pengenalan Paribasa Bali Berbasis Mobile.

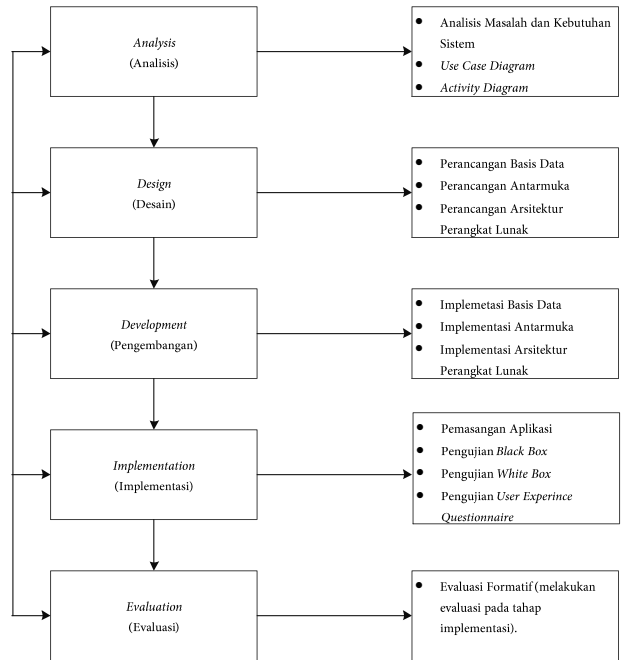

Gambar 1 Model Penelitian ADDIE pada aplikasi Paribasa Bali

\section{A. Analysis (analisis)}

Tahap ini merupakan tahap pertama dimana melakukan analisis maupun keinginan yang diharapkan oleh pengguna terhadap aplikasi yang dikembangkan. Tahap analisis ini mencangkup analisis masalah beserta usulan solusi dan analisis kebutuhan sistem. Pada proses analisis dapat dilakukan dengan mengumpulkan informasi maupun kebutuhan melaui studi literatur, seperti menyebarkan angket, mencari penelitian terkait, buku, jurnal maupun wawancara dengan narasumber terkait penelitian yang dikembangkan.

\section{B. Design (desain)}

Tahap desain merupakan tahap kedua setelah sebelumnya melalui tahap analisis. Pada tahap ini merupakan tahapan perancangan sistem agar sistem yang akan dikembangkan bisa menyelesaikan seluruh aktivitas dengan baik. Adapun perancangan yang dilakukan dalam Aplikasi Pengenalan Paribasa Bali Berbasis Mobile, yaitu perancangan basis data, antarmuka, dan arsitektur perangkat lunak.

\section{Development (pengembangan)}

Tahap ini merupakan tahap dimana segala perancangan yang telah dibuat baik perancangan basis data, antarmuka, dan arsitektur perangkat lunak dieksekusi menjasi sebauh aplikasi yang tersusun secara utuh. Proses eksekusi ini berupa translasi dari desain yang sudah dibuat sebelumnya ke dalam baris kode program dengan menggunakan perangkat software pendukung sesuai dengan kebutuhan. 


\section{Implementation (implementasi)}

Tahap implementasi ini merupakan tahapan dimana peneliti melakukan suatu pengujian dan validasi terhadap aplikasi yang dikembangkan. Proses tahap ini bertujuan untuk memastikan aplikasi yang dibangun berdasarkan rancangan yang telah dibuat, sudah benar dan berjalan dengan baik. Adapun beberapa proses pengujian yang dilakukan diantaranya, pengujian black box, white box, dan user experince questionnaire (UEQ).

\section{E. Evaluation (evaluasi)}

Tahap ini merupakan tahap pengolahan data dari hasil pengujian validasi yang dilakukan pada tahap implementasi yang disebut dengan evaluasi sumatif. Pada evalusi ini akan dilakukan penyimpulan dari hasil olah data yang diperoleh, apakah aplikasi yang sudah dikembangkan sesuai dengan kriteria standar yang ditentukan dan apakah aplikasi yang sudah dikembangkan layak atau tidak untuk digunakan oleh masyarakat luas. Pada tahapan ini nantinya juga dilakukan revisi jika aplikasi tersebut tidak memenuhi standar kualtias yang ditentukan.

\section{HASIL \& PEMBAHASAN}

\section{A. Hasil Penelitian}

Berdasarkan metode dan model penelitian yang telah dipaparkan sebelumnya, beberapa tahap penelitian yang dilakukan dalam penelitian ini yaitu, tahap Analyze (analisis), Design (desain), Development (pengembangan), Implementation (implementasi), dan Evaluation (evaluasi). Hasil dari setiap tahapan penelitian pada Aplikasi Paribasa Bali Berbasis Mobile dengan masing masing tahapan Analysis, Design, Development, Implementation, Evaluation (ADDIE) adalah sebagai berikut:

\section{a) Analysis (analisis)}

Tahap analisis merupakan tahap awal dari proses penelitian ini terhadap aplikasi yang dikembangkan. Pada proses analisis mencangkup analisis masalah beserta usulan solusi dan analisis kebutuhan sistem yang meliputi kebutuhan fungsional maupun non fungsional, kebuthan perangkat keras, dan kebutuhan perangkat lunak. Setelah itu, maka dilakukan pemodelan sistem dengan menggunakan UML (Unified Modelling Language) yang meliputi, Use Case Diagram dan Activty Diagram.

Berikut solusi yang diimplementasikan ke aplikasi pengenelan Paribasa Bali berbasis mobile.

1. Memberikan informasi terkait Paribasa Bali beserta contoh dari Paribasa Bali tersebut.

2. Memberikan kesempatan untuk berpatisipasi dalam mengembangkan Paribasa Bali baru.
Berdasarkan dari tahap analisis kebutuhan sistem yang sudah dilakukan, maka didapatkan kebutuhan fungsional dan non fungsional yang diperlukan dalam membangun aplikasi ini.

1. Kebutuhan Fungsional dari pengguna berupa aplikasi mobile

a. Pengguna mampu daftar dengan email dan password.

b. Pengguna mampu login dengan email dan password.

c. Pengguna mampu menampilkan, melakukan pencarian serta filter kamus Paribasa Bali.

d. Pengguna mampu menampilkan, menyukai kiriman pengguna lain dan melakukan pencarian serta filter kiriman Paribasa Bali.

e. Pengguna mampu membagikan atau menambahkan Paribasa Bali.

f. Pengguna mampu menampilkan pemberitahuan dari sistem.

g. Pengguna mampu menampilkan profile pengguna.

h. Pengguna mampu menampilkan riwayat kiriman Paribasa Bali.

i. Pengguna mampu menampilkan sekilas Paribasa Bali.

j. Pengguna mampu keluar dari aplikasi

2. Kebutuhan Non Fungsional

a. Aplikasi dapat dengan mudah digunakan dan tampilan antarmuka aplikasi yang menarik dan tidak membingungkan.

b. Aplikasi hanya dapat dijalankan pada perangkat smartphone sistem operasi android.

c. Aplikasi harus terubung dengan koneksi internet.

3. Kutuhan Perangkat Keras

a. Laptop: Prosesor : Intel(R) Core(TM) i3-4030U CPU @ $1.90 \mathrm{GHz}, \mathrm{RAM}: \quad$ DDR3L 4 GB, Hard Disk : 500 GB, Sistem Operasi : Windows 8.1 Pro

b. Smartphone Android: Sistem Operasi : Android 5.1 (Lollipop), Chipset : Qualcomm MSM8916 Snapdragon 410, CPU: Quad-core $1.2 \mathrm{GHz}$ Cortex-A53, Memory (RAM) : 2GB, Layar : 5 Inchi.

4. Kebutuhan Perangkat Lunak
a. Database : Firebase
b. Framework : React Native
c. Text Editor: Visual Studio
d. Desain Interface : Mockplus 
ISSN 2252-9063

Pemodelan sistem dilakukan dengan menggunakan UML (Unified Modelling Language). Adapun diagram UML yang digunakan dalam penelitian ini sebagai representasi alur kerja dari aplikasi diantaranya, Use Case Diagram dan Activity Diagram.

\section{Use Case Diagram}

Use Case Diagram digunakan untuk mengetahui fungsi yang diharapkan dari sebuah sistem dan siapa yang memiliki berhak menggunakan fungsi tersebut. Pada Gambar 2 menunjukan bahwa terdapat 2 (dua) aktor dalam aplikasi yang dikembangkan ini yaitu, administrator dan pengguna. Gambar 2 merupakan Use Case Diagram dari Aplikasi Pengenalan Paribasa Berbasis Mobile Bali.

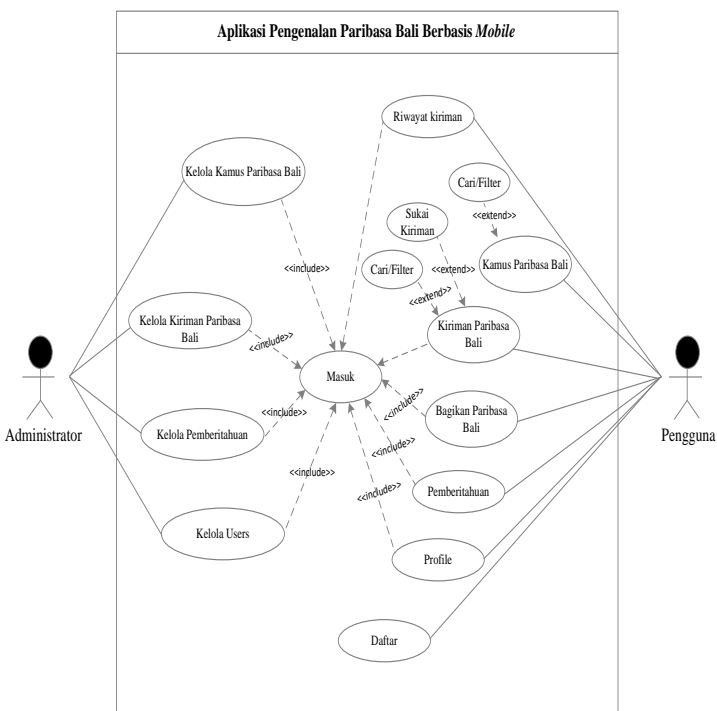

Gambar 2. Use Case Diagram dari Aplikasi Pengenalan Paribasa Berbasis Mobile Bali.

\section{Activity Diagram}

Activity Diagram ini menggambarkan berbagai alur aktivitas dalam sistem yang sedang dirancang, bagaimana masing-masing alur berawal, decision yang mungkin terjadi, dan bagaimana alur berakhir. Berikut ini akan dijelaskan activity diagram dari masing-masing proses aplikasi yang dikembangkan. Berikut beberapa activity diagram yang ada pada Aplikasi Pengenalan Paribasa Berbasis Mobile Bali, meliputi activity diagram kamus Paribasa Bali dapat dilhat pada Gambar 3 dan activity diagram kamus Paribasa Bali dapat dilihat pada gambar 4

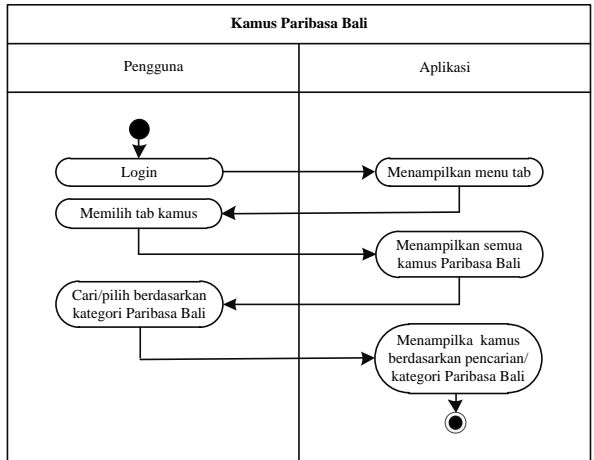

Gambar 3. Activity Diagram Kamus Paribasa Bali

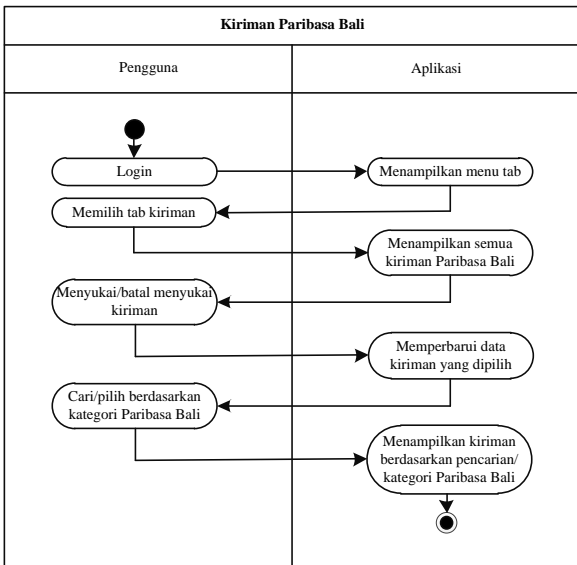

Gambar 4. Activity Diagram Kiriman Paribasa Bali

\section{b) Design (desain)}

Tahap desain merupakan proses multi langkah berfokus pada rancangan dari aplikasi yang dikembangkan. Pada tahapan ini mentranslasi kebutuhan atau fitur dari tahap analisis menuju ke repersentatif desain yang dapat dibagi menjadi 3, diantaranya perancangan basis data, perancangan antarmuka, dan perancangan arsitektur sistem.

a. Perancangan Basis Data

Adapun rancangan basis data yang digunakan dalam aplikasi Paribasa Bali ini berupa firebase. Berikut beberapa rancangan basis data yang ada pada Aplikasi Pengenalan Paribasa Berbasis Mobile Bali, meliputi perancangan data kamus dapat dilhat pada Gambar 5 dan perancangan data kiriman dapat dilihat pada Gambar 6.

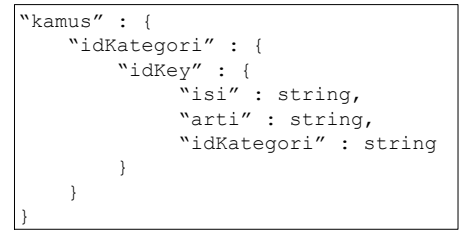

Gambar 5. Rancangan Data Kamus 


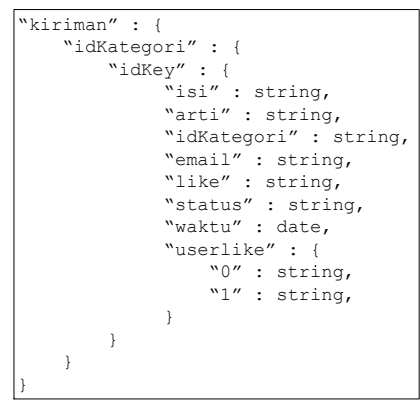

Gambar 5. Rancangan Data Kiriman

b. Perancangan Antarmuka

Berikut beberapa rancangan basis data yang ada pada Aplikasi Pengenalan Paribasa Berbasis Mobile Bali, meliputi rancangan antarmuka masuk dapat dilhat pada gambar 6 dan rancangan antarmuka kamus Paribasa Bali dapat dilihat pada gambar 7 .

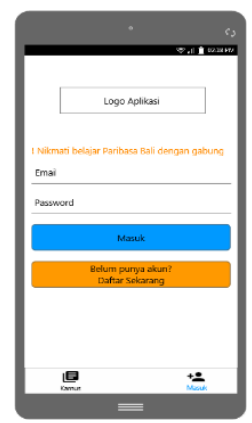

Gambar 7. Rancangan Antarmuka Kamus Paribasa Bali

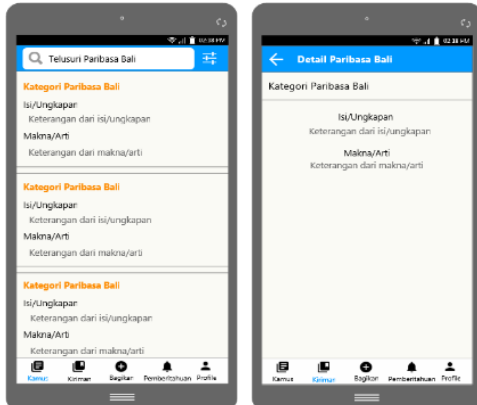

Gambar 8. Rancangan Antarmuka Kamus Paribasa Bali

\section{c. Perancangan Arsitektur Sistem}

Arsitektur perangkat lunak menjelaskan susunan sitem yang terdiri dari komponen software, atribut dari komponen dan hubungan antar komponennya. Pada aplikasi pengenalan Paribasa Bali berbasis mobile dan aplikasi web admin yang dapat terhubung langsung ke server firebase. Perancangan arsitektur sistem dapat dilihat pada Gambar 9.

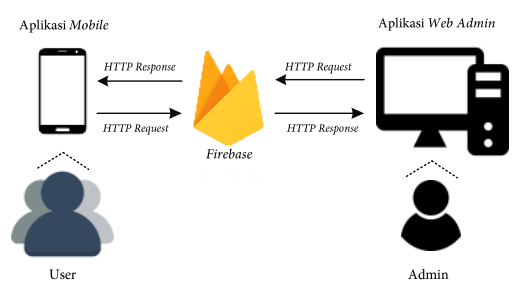

Gambar 9. Rancangan Arsitektur Sistem

\section{c) Development (pengembangan)}

Tahap pengembangan merupakan tahap proses eksekusi ke dalam baris kode program dari semua perancangan yang sudah dibuat. Pengembangan Aplikasi Paribasa Bali Berbasis Mobile menggunakan bahasa pemrograman JS (Javascript) dengan framwork react native.

Berikut hasil implementasi layar antarmuka yang dilakukan sesuai dengan hasil rancangan antarmuka yang telah dibuat:

a. Layar Antarmuka Masuk

Implementasi antarmuka masuk merupakan tampilan pertama untuk pengguna dan sebelum masuk ke screen berikutnya pengguna terlebih dahulu mengisi email dan kata sandi dengan benar. Pada Gambar 10 dapat dilihat implementasi antamuka masuk.

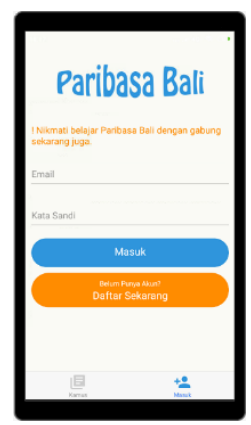

Gambar 10. Implementasi Antarmuka Masuk

b. Layar Antarmuka Daftar

Implementasi antarmuka daftar merupakan tampilan untuk pengguna melakukan proses daftar akun dengan melengkapi form data, seperti email, nama, JK, sandi,. Pada Gambar 11 dapat dilihat impelementasi antarmuka daftar. 


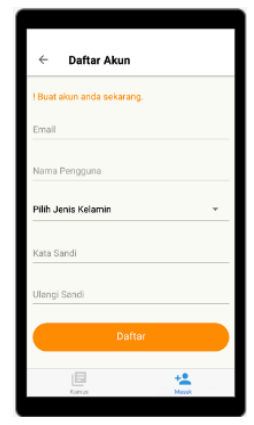

Gambar 11. Implementasi Antarmuka Daftar

c. Layar Antarmuka Kamus Paribasa Bali

Implementasi antarmuka kamus Paribasa Bali merupakan tampilan untuk pengguna melihat kamus Paribasa Bali yang dilengkapi dengan pencarian dan filter berdasarkan kategori Paribasa Bali. Pada Gambar 12 dapat dilihat impelementasi antarmuka kamus Paribasa Bali.

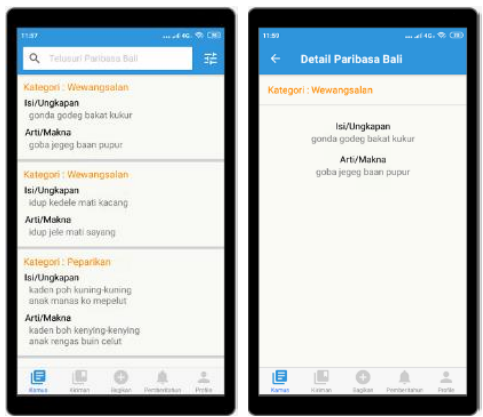

Gambar 12. Implementasi Antarmuka Kamus Paribasa Bali

d. Layar Antarmuka Kiriman Paribasa Bali

Implementasi antarmuka kiriman Paribasa Bali merupakan tampilan untuk pengguna melihat kiriman Paribasa Bali dari semua pengguna yang dilengkapi dengan tombol menyukai kiriman lain, pencarian, dan filter berdasarkan kategori Paribasa Bali. Pada Gambar 13 dapat dilihat implementasi antamuka kiriman Paribasa Bali.

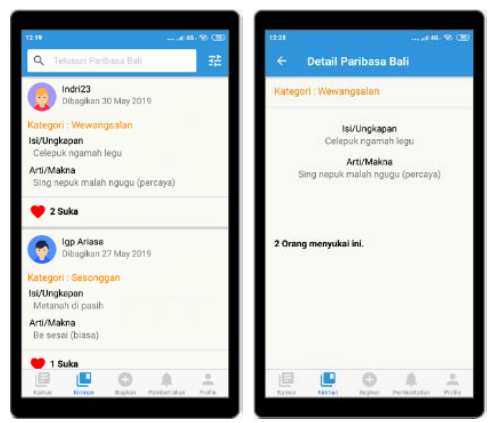

Gambar 13. Implementasi Antarmuka Kiriman Paribasa Bali e. Layar Antarmuka Bagikan Paribasa Bali

Implementasi antarmuka bagikan Paribasa Bali merupakan tampilan untuk pengguna melakukan proses membagikan Paribasa Bali baru ke aplikasi dengan melengkapi form data, seperti kategori, isi/ungkapan, dan arti/makna. Pada Gambar 14 dapat dilihat implementasi antamuka bagikan Paribasa Bali.

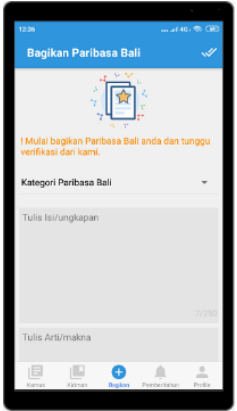

Gambar 14. Implementasi Antarmuka Bagikan Paribasa Bali

f. Layar Antarmuka Pemberitahuan

$$
\text { Implementasi antarmuka pemberitahuan }
$$
merupakan tampilan untuk pengguna melihat pemberitahuan dari sistem terkait status verifikasi kiriman Paribasa Bali pengguna berupa keterangan. Pada Gambar 15 dapat dilihat implementasi antamuka pemberitahuan.

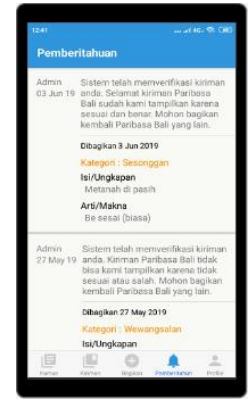

Gambar 15. Implementasi Antarmuka Pemberitahuan

g. Layar Antarmuka Profile

Implementasi antarmuka profile merupakan tampilan untuk pengguna melihat profile dari pengguna, seperti foto, email, nama lengkap, dan jenis kelamin. Pada Gambar 16 dapat dilihat implementasi antamuka profile. 


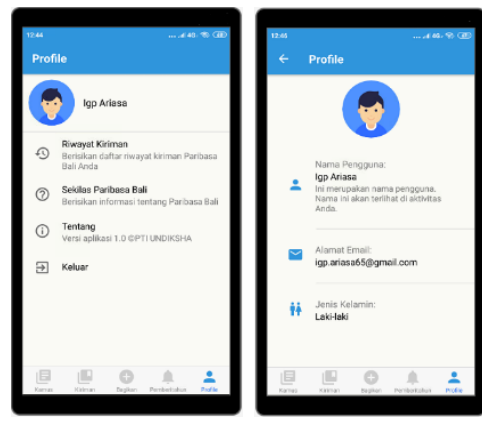

Gambar 16. Implementasi Antarmuka Profile

h. Layar Antarmuka Riwayat Kiriman

Implementasi antarmuka riwayat kiriman merupakan tampilan untuk pengguna melihat riwayat kiriman pengguna dibedakan berdasarkan status proses verifikasi, seperti sukses verifikasi dan gagal verifikasi. Pada Gambar 17 dapat dilihat implementasi antamuka riwayat kiriman.

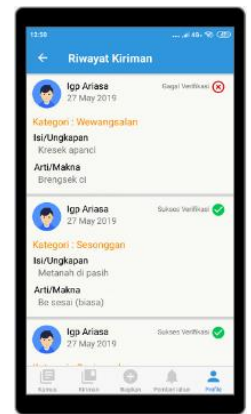

Gambar 17. Implementasi Antarmuka Riwayat Kiriman

\section{i. Layar Antarmuka Sekilas Paribasa Bali}

Implementasi antarmuka sekilas Paribasa Bali merupakan tampilan untuk pengguna melihat informasi Paribasa Bali, seperti pengertian dan contoh detail di masing-masing kategori. Pada gambar 18 dapat dilihat implementasi antamuka sekilas Paribasa Bali.

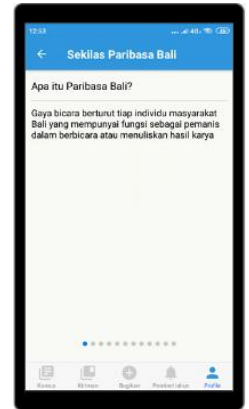

Gambar 18. Implementasi Antarmuka Sekilas Paribasa Bali

\section{d) Implementation (implementasi)}

Tahap implementasi adalah tahap dimana saatnya aplikasi yang dibangun dapat diperkenalkan dan dilakukan pengujian kelayakan produk dengan tujuan untuk memastikan aplikasi yang telah dibangun berdasarkan rancangan yang dibuat dan dapat berjalan dengan baik. Berikut adalah hasil pengujian yang dilakukan.

a. Pengujian Fungsional (black box)

Pengujian black box ini dilakukan untuk mengetahui aplikasi yang dibuat sudah berjalan dengan baik dan benar. Pengujian dilaksanakan pada hari senin, 27 Mei 2019 dengan beberapa pengguna aplikasi. Pengujian dilakukan oleh Kadek Ari Darma Putra, I Gusti Putu Ariasa, dan Made Wiranata S.Pd sebagai pengguna, sedangkan peneliti yang selaku administator juga akan mengisi angket yang telah disediakan

b. Pengujian Struktural (white box)

Pengujian white box dilakukan untuk mengetahui kebenaran dari proses pemanggilan source code atau kode program aplikasi. Pengujian dilakukan oleh peneliti sesuai dengan angket yang telah disediakan

c. Pengujian User Experince Questionnaire (UEQ)

Pengujian UEQ dilakukan untuk mengetahui kepuasaan pengguna yang mengacu presepsi, perasaan, dan pendapat saat mengunakan aplikasi. Pengujian dilaksanakan mulai dari tanggal 30 Mei 2019 sampai dengan 7 Juni 2019.

\section{e) Evaluation (evaluasi)}

Berdasarkan hasil pengujian black box, white box, dan user experince questionnaire (UEQ) yang telah dilakukan. Pada tahap evaluasi merupakan tahap penyimpulan dari hasil olah data yang diperoleh dari tahap implementasi yang sudah dilakukan meliputi, pengujian black box, white box, dan user experince questionnaire (UEQ).

a. Hasil Pengujian Black Box

Berdasarkan hasil dari pengujian black box terhadap aplikasi pengenalan Paribasa Bali berbasis mobile diperoleh kesimpulan bahwa, semua kelas uji sangat berhasil dan sesuai dengan hasil yang diharapkan.

\section{b. Hasil Pengujian White Box}

Berdasarkan hasil dari pengujian white box terhadap aplikasi pegenalan Paribasa Bali berbasis mobile diperoleh kesimpulan bahwa, semua proses source code atau kode program dapat bekerja dengan baik dan sesuai dengan fungsinya. 


\section{c. Hasil Pengujian UEQ}

Berdasarkan hasil dari pengujian UEQ terhadap aplikasi Paribasa Bali berbasis mobile. Respon pengguna dinyatakan dapat memberikan hal positif. Hasil tersebut dibuktikan dengan rata-rata pencapaian user experience berada pada tingkatan yang sangat memuaskan (excellent). Hasil dari daya tarik (2.13), dari segi kejelasan (2.08), effesiensinya (2.03), ketepatan (2.06), stimulasi (2.15) dan pembaruan (2.11).

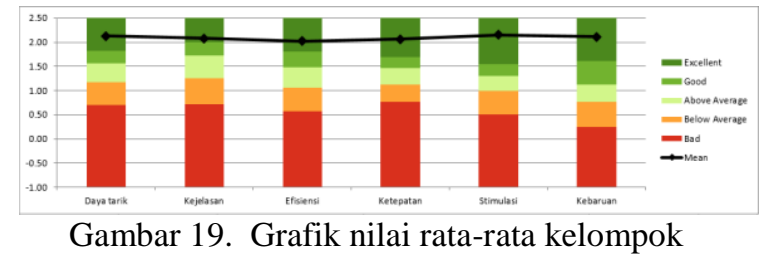

\section{B. Pembahasan}

Paribasa Bali merupakan gaya bicara berturut setiap individu masyarakat Bali yang mempunyai fungsi sebagai pemanis dalam berbicara atau menuliskan hasil karya. Paribasa Bali dapat dibagi menjadi sepuluh jenis, diataranya (1) Wewangsalan, (2) Peparikan, (3) Sesonggan, (4) Sesenggakan, (5) Sesawangan, (6) Bladbadan, (7) Sloka, (8) Sesapan, (9) Raos ngempelin, (10) Cacimpedan. Berdasarkan hasil mengadakan survery terhadap 35 orang responden mengenai masalah serta kondisi Paribasa Bali saat ini di masyarakat umum. Berdasarkan dari hasil tersebut maka diketahui bahwa, sebanyak $62 \%$ responden mengetahui manfaat dalam mempelajari Paribasa Bali. Selanjutnya, sebanyak $25 \%$ responden mengetahui secara pasti tentang Paribasa Bali dan adapun sisanya sebanyak $75 \%$ responden tidak mengatahui secara pasti tentang Paribasa Bali. Semua responden setuju jika Paribasa Bali sebagai media belajar dan dilestarikan melalui aplikasi mobile. Berdasarkan hasil pengembangan dilakukan bahwa, aplikasi pengenalan Paribasa Bali berbasis mobile dikembangkan dengan model penelitian ADDIE antara lain meliputi, analisis, desain, pengembangan, implementasi, dan evaluasi. Pada tahap analisi mencangkup analisis masalah

beserta usulan solusi dan analisis kebutuhan sistem. Berdasarkan hasil analisis, maka selanjutnya dilakukan suatu pemodelan sistem perangkat lunak beorientasi objek dengan menggunakan UML (Unified Modelling Language). Adapun diagram UML yang digunakan yaitu, Use Case Diagram dan Activty Diagram. Pada tahap desain merupakan tahapan perancangan sistem yang dikembangkan. Adapun perancangan yang sistem, yaitu perancangan basis data, antarmuka, dan arsitektur perangkat lunak. Selanjutnya, tahap pengembangan merupakan proses eksekusi translasi dari desain yang sudah dibuat sebelumnya ke dalam baris kode program dengan menggunakan perangkat software pendukung sesuai kebutuhan, seperti database firebase, framework react native untuk aplikasi mobile, dan bahasa pemrograman PHP untuk aplikasi web dengan bantuan visual studio sebagai text editor. Selama tahap pengembangan ini terdapat beberapa kelemahan dari aplikasi yang dibuat yakni, aplikasi hanya baru mampu menyedikan fitur masuk atau login melalui email beserta verifikasinya, pencarian Paribasa Bali hanya mampu melalui text yang diketik, foto profil dari pengguna berupa image yang sudah ditentukan sesuai dengan jenis kelamin, dan belum tersedia notifikasi kepada pengguna untuk data baru pada kamus Paribasa Bali, kiriman Paribasa Bali, dan pemberitahuan status verifikasi kiriman. Tahapan keempat yakni, tahap implementasi merupakan pelaksanaan pengujian dan validasi terhadap aplikasi yang dikembangkan. Berikut ini beberapa proses pengujian yang akan dilakukan, yaitu black box, white box, dan user experince questionnaire (UEQ). Tahapan terakhir adalah melakukan evaluasi meruapakan tahap pengolahan data dari hasil pengujian validasi yang dilakukan pada tahap implementasi.

Sebelum dilakukannya pengujian, aplikasi terlebih dahulu dipasang pada smartphone. Adapun sistem operasi android minimum yang selanjutnya aplikasi sudah dapat diuji coba. Pengujian aplikasi ini dilakukan untuk mengetahui tingkat kelemahan serta kesalahan, sehingga nantinya dapat diperbaiki lagi untuk mengurangi kelemahan yang terjadi sebelum diimplementasikan ke masyarakat luas.

Berdasarkan hasil pengujian white box yang dilakukan untuk mengetahui kebenaran dari proses pemanggilan source code atau kode program aplikasi. Pada pengujian ini dilakukan oleh peneiti sendiri sesuai dengan angket yang dirancang. Adapun hasil dari pengujian white ini yaitu, semua proses source code atau kode program dapat bekerja dengan baik dan sesuai dengan fungsinya. Selanjutnya pada pengujian black box yang dilakukan untuk mengetahui aplikasi yang dibuat sudah berjalan dengan baik dan benar. Pada pengujian black box dilakukan oleh 3 (tiga) orang responden dan peneliti. Adapun hasil dari pengujian black box ini, yaitu semua kelas uji sangat berhasil dan sesuai dengan hasil yang diharapkan.

Berdasarkan hasil pengujian user experince questionnaire (UEQ) untuk mengetahui penilaian pengguna tentang kelayakan dan respon pengguna terhadap aplikasi

pengenalan Paribasa Bali berbasis mobile. Pengujian UEQ dilakukan oleh 20 (dua puluh) orang responden. Adapun hasil respon pengguna dinyatakan dapat memberikan hal positif. Hasil dari daya tarik aplikasi tergolong sangat baik (2.13), dari segi kejelasan aplikasi sangat baik (2.08), dalam hal effesiensinya aplikasi sangat baik (2.03), ketepatan aplikasi sangat baik (2.06), stimulasi aplikasi sangat baik (2.15), dan pembaruan juga dinyatakan sangat baik (2.11). 


\section{SIMPULAN}

Berdasarkan hasil penelitian Aplikasi Pengenalan Paribasa Bali Berbasis mobile yang telah dilakukan, maka diperoleh simpulan sebagai berikut.

1. Aplikasi Pengenalan Paribasa Bali Berbasis Mobile yang telah berhasil dirancang dengan pemodelan sistem dengan menggunakan UML (Unified Modelling Language) dan diimplementasikan dengan framework react native dengan menggunakan bahasa pemrograman Javascript.

2. Respon pengguna melalui pengujian UEQ terhadap aplikasi pengenalan paribasa Bali berbasis mobile berada pada tingkatan yang sangat memuaskan (excellent), meliputi kelompok daya tarik (2.13), kejelasan (2.08), effesiensi (2.03), ketepatan (2.06), stimulasi (2.15), dan kebaruan (2.11).

Adapun saran yang bisa peneliti sampaikan untuk penelitian sejenis dengan Aplikasi Paribasa Bali Berbasis Mobile, yaitu:

1. Diharapkan pengembang selanjutnya dapat menambahkan fitur masuk atau login melalui sosial media, seperti facebook, twitter, dan google.

2. Diharapkan pengembang selanjutnya dapat menambahkan fitur suara pada saat pencarian maupun bagikan contoh Paribasa Bali.

3. Diharapkan pengembang selanjutnya dapat menambahkan foto profil melalui kamera maupun galeri pada smartphone.

4. Diharapkan pengembang selanjutnya dapat menambahkan notifikasi untuk data baru kamus Paribasa Bali, kiriman Paribasa Bali, pemberitahuan status verifikasi.

\section{REFRENSI}

[1]. Ginarsa, I. K. (1985). Paribasa Bali. Denpasar: CV. Kayumas Agung.

[2]. Mawanti, D. (2014). Pengembangan kamus visual multi bahasa (Arab-Inggris-Indonesia-Jawa) untuk PAUD (Pendidikan Anak Usia Dini) berbasis kearifan lokal. Semarang: LP2M IAIN Walisongo.

[3]. Safaat, N. (2015). Rancang Bangun Aplikasi Multipatform. Bandung: Informatika Bandung.
[4]. Wijonarko, D., \& Aji, R. F. (2018). Perbandingan Phonegap dan React Native sebagai Framework Pengembangan Aplikasi Mobile. Jurnal Managemen Informatika \& Sistem Informasi Volume 1 No 2 , 1-7.

[5]. Tanjung, R., \& Parsika, F. (2014). Pengembangan Aplikasi Multimedia Pengenalan dan Pembelajaran Origami Dengan Pendekatan ADDIE. Seminar Nasional Informatika 2014, 128-133. 